\title{
Occurrence and Antibiotic Sensitivity of Bacterial Strains Isolated from Nile Tilapia, Oreochromis niloticus Obtained in Ibadan, Southwest Nigeria
}

\author{
A. M. Tiamiyu*, M. O. Soladoye, T. T. Adegboyega, M. O. Adetona \\ Department of Biological Sciences, Faculty of Pure \& Applied Sciences, Southwestern University Nigeria, \\ ljebu-Ode, Nigeria \\ Email: ${ }^{\text {tiaadebisi2014@yahoo.com }}$
}

Received 19 March 2015; accepted 30 April 2015; published 6 May 2015

Copyright (C) 2015 by authors and Scientific Research Publishing Inc.

This work is licensed under the Creative Commons Attribution International License (CC BY). http://creativecommons.org/licenses/by/4.0/

(c) (i) Open Access

\section{Abstract}

The bacteriological quality of both wild and cultured Nile Tilapia, Oreochromis niloticus, sourced in some area of Ibadan, Southwest, Nigeria was studied. Bacteria flora of the skin and stomach of fish samples were examined and compared statistically (t-test independent). The resistance of bacterial isolates to commonly used antibiotics was also studied. Total aerobic bacteria count [colony forming unit: $\mathrm{CFU}=159.50 .13 \pm 72, \mathrm{t}<0.01]$ with significant difference in the skin and Enterobacteriaceae count $[(\mathrm{CFU})=74.08 \pm 5.55]$ with significant difference in the stomach were obtained in the Nile tilapia. The bacteria in the genera Staphylococcus, Escherichia, Proteus, Bacillus, Klebsiella, Micrococcus, Serratia, Pseudomonas, Salmonella and Streptococcus were isolated and had been proven to be of great public health significance. About $87.5 \%$ of the tested isolates were resistant to augmentin, $83.33 \%$ to cotrimoxazole and nalidixic acid. In addition, $79.17 \%$ of the isolates were resistant to tetracycline, $75.0 \%$ to amoxicillin, $54.17 \%$ to nitrofuratoin, $50.00 \%$ to ofloxacin and $\mathbf{2 9 . 1 7 \%}$ to gentamicin. Among the eight antibiotics tested, six patterns of drug resistance were obtained and all of them were multiple drug resistance with three to eight. The public health implications of these observations are discussed.

\section{Keywords}

Antibiotic Sensitivity, Bacteria Flora, Nile Tilapia, Public Health

\footnotetext{
${ }^{*}$ Corresponding author.
} 


\section{Introduction}

The increase in human population and report of large number of undernourished or starving people especially in the developing countries has made the need for food production a major worldwide issue of concern [1]. Thirtyfive (35) grams of animal protein per day per person is recommended by the Food and Agricultural Organization [FAO], less than 7 grams are consumed by an average Nigerian [2].

With the ever-increasing growth witnessed by major sources of animal proteins such as livestock and poultry industries with their high market prices and the partial ban on importation of frozen food in Nigeria, many Nigerians suffer protein deficiency due to low protein intake [3] [4]. Therefore, there is need for more focus on fish production. Due to faster growth rate, tolerance to harsh environment and easy to culture technique and abundant capture from wild, tilapia offers the possibility of alternative sources of protein to many Nigerians.

While fish are no more hazardous than other animal protein sources, many pathogenic microorganisms and parasites conceivably are transmitted to humans through fish [5]. The occurrence of pathogenic microorganisms in freshwater fish could exist anytime sewage from human or animal origin is discharged into natural water bodies. Fish and shell fish spoil rapidly because of bacteria action [6] [7].

The fish and shell fish provide good substrate for the microorganisms due to their meat properties. Fish and shellfish may carry pathogenic bacteria which is found in natural aquatic environments, contaminated water or handling environments [8]. Of significant interest are those bacteria that are capable of causing food poisoning in humans.

More so, in Nigeria, little is known about the occurrence of antibiotics resistant bacteria in freshwater animals. As far as intensive fish culture goes, a large amount of fish food and antibiotics have been used to increase production and to protect the fish from diseases. Consequently, a large portion of feeds and antibiotic enter the water as wastes, causing water pollution. Based upon the shortage of information about the bacterial density and antimicrobial resistance in Nile tilapia sampled from feral and cultured ponds in Nigeria. The purpose of this study was to compare the bacterial load of microbes between the skin and stomach of Wild and Cultured Nile Tilapia (Oreochromis niloticus) and the susceptibility of the isolates to commonly used antimicrobial agents.

\section{Materials and Methods}

Study location: Nile tilapiasamples $(19.55 \pm 2.38 \mathrm{~cm} ; 65.63 \pm 9.26 \mathrm{~g}$, mean \pm SEM) were drawn from a fishery institute fish pondsin Ibadan, southwest local government, Oluyole Estate, Ibadan. The area of the pond is $20,045 \mathrm{~m}^{2}$ with depth of $1.0 \mathrm{~m}$. Nile tilapia $(16.01 \pm 1.45 \mathrm{~cm}, 99.83 \pm 21.76 \mathrm{~g}$, mean $\pm \mathrm{SEM})$ were also sampled from Eleyeleriver in Ibadan North West local government, Onireke Ibadan. The area and depth of the river were not determined.

\section{Collection of Fish Samples}

Live Nile tilapia (Oreochromis niloticus) was randomly collected from the study sites. The fish samples were transported directly to the food and meat hygiene laboratory of Department of Veterinary Public Health and Preventive Medicine, University of Ibadan in an insulated box filled with cool packs (Jonny Plastic Ice, Pelton Shepard, Stockon, CA, USA) within two hours of sampling at $4^{\circ} \mathrm{C}$ according to APHA, 1998. The samples were caught by a local fishing gear and by cast net. Samples were drawn between 8:00 am and 10:00 am in each occasion at periodic interval of seven days.

\section{Bacteriological Examination of the Fish Samples}

The fish samples were processed for bacteriological analyses within 2 - 4 hr of sampling following aseptic techniques. The bacteriological media namely, Nutrient Agar (NA) and MacConkey Agar (MAC) were used to prepare the culture media [9].

The bacteria isolates from each specimen were obtained aseptically from the skin $\left(1 \mathrm{~cm}^{2}\right)$ and stomach $(1 \mathrm{~g}$ portion). Each of the samples was placed in $10 \mathrm{ml}$ distilled water. The stock solution was serially diluted. An aliquot of $0.1 \mathrm{~mL}$ of each desired solution was spread on each of the culture medium (using spread plate method) and incubated for $18-24 \mathrm{hr}$ at $37^{\circ} \mathrm{C}$. The colony forming counts per gram of sample was determined using standards method [10] [11]. Bacterial density as colony forming unit $\left(\mathrm{cfu}^{\mathrm{c}} \mathrm{cm}^{2}\right)$ or $\mathrm{g}^{-1}$ for two replicates were initially averaged and used for final calculation. The results were converted to logarithms in base ten. 
All equipment and chemicals used were sterilized properly prior to use. The single colony was further sub cultured on freshly prepared NA and MAC for colonial purification. The pure bacterial isolates were subjected to variety of primary and biochemical tests. Each bacterium isolates was subjected to variety of primary and biochemical tests according to standard taxonomic schemes [12].

\section{Antibiotic Sensitivity Test}

The antibiotic sensitivity tests of randomly selected bacterial isolates were tested for their sensitivity to antibiotics by means of a disc diffusion method [13]. It was investigated using GBMTS discs (Abtek biological Ltd.) containing the following antibiotics: Augmentin (Aug), $30 \mu g$; Amoxyclin (Amx), $25 \mu g$; Cotrimoxazole (Cot), $25 \mu \mathrm{g}$; Gentamicin (Gen), $10 \mu \mathrm{g}$; Nalidixic acid (Nal); $30 \mu \mathrm{g}$; Nitrofuratoin (Nit), $100 \mu \mathrm{g}$; Ofloxacin (Ofx); $5 \mu \mathrm{g}$; and Tetracycline (Tet) $10 \mu \mathrm{g}$.

The commercial antibiotics were placed on nutrient agar plates previously seeded with an $18-24 \mathrm{hr}$ aged culture of each test organism using sterile glass spreader. The plates were incubated at $37^{\circ} \mathrm{C}$ for $48 \mathrm{hr}$, after which zones of inhibition were examined and interpreted accordingly [14]. The resistance pattern of each isolate was constructed from the antibiogram. Earlier, the potencies of the entire antibiotic used in the study were confirmed using susceptible Escherichia coli strains.

Statistical Analysis: The results obtained from the study were subjected to a statistical analysis (SAS, 2003) using t-test as outlined by 36 Values at $p<0.05$ were considered significant.

Result and Discussion: The microbial load of heterotrophic bacteria isolated from skin and stomach of the fish are as presented in Table 1. The total heterotrophic bacteria count ranged from $104.1 \pm 9.03$ to $159.50 \pm$ 13.72, mean $\left( \pm\right.$ SEM) for cultured and wild Nile tilapia. The highest microbial load of $159.50 \pm 13.72\left(\log _{10} \mathrm{cfu} /\right.$ $\mathrm{cm}^{2}$ 13.20) was obtained from the skin of Nile tilapia captured from wild while the least occurrence of bacteria load of $104.1 \pm 9.03\left(\log _{10} \mathrm{cfu} / \mathrm{g} 13.02\right)$ was also found in the stomach of Nile tilapia obtained from the same source.

For the wild Nile tilapia, the microbial load of the skin was significantly higher than that of the stomach. This could be due to mass pollution of the environment or scales on the skin of tilapia that can harbor feed matter suitable for the survival of the bacteria than the stomach.

The acidic environment $(\mathrm{pH}<2)$ of Nile tilapia stomach which ruptures the cell wall of bacteria [15] could be responsible for low survival rate of bacteria in the stomach of Nile tilapia than that harbor the skin. Comparing the total bacteria load of the skin $\left(143.67 \pm 19.25, \log _{10} \mathrm{cfu} / \mathrm{cm}^{2} 13.16\right)$ and stomach $\left(104.72 \pm 17.19, \log _{10} \mathrm{cfu} / \mathrm{g}\right.$ 13.02) of fish sourced from cultured ponds, there was no significant difference however higher bacteria count was observed on the skin of the fish which could be due to the presence of scales on the skin that can harbor feed matter suitable for the survival of the bacteria.

The Enterobacteriaceae count of the skin and stomach of wild and cultured Nile tilapia ranged from $49.00 \pm$ 4.13, $\log _{10} \mathrm{cfu} / \mathrm{cm}^{2} 13.02$ to $74.08 \pm 5.55, \log _{10} \mathrm{cfu} / \mathrm{g} 13.02$ mean \pm SEM as shown in Table 2 .

A significantly higher count of Enterobacteriaceae was obtained in the stomach of wild tilapia compared to the skin. This could be due to ability of some enteric bacteria to withstand acidic environment of the stomach of Nile tilapia [15]. Contrary to what was observed in the total aerobic bacteria count in the skin and stomach of fish samples, the Enterobacteriaceae count in the stomach of wild and cultured Nile tilapia was higher than count on the skin.

Table 1. Total bacteria load on skin and in stomach of Nile tilapia (Oreochromisniloticus) $(\mathrm{n}=12$ fishes $\times$ duplicates readings).

\begin{tabular}{cccc}
\hline & \multicolumn{2}{c}{ Sample Body Parts } \\
\hline Sources & Skin $\left(\mathrm{cfu} / \mathrm{cm}^{2}\right)$ & Stomach $(\mathrm{cfu} / \mathrm{g})$ & t-Value \\
\hline Wild CFU $\left(\times 10^{11}\right)$ & $159.50+13.72$ & $104.17+9.03$ & $369^{* * *}$ \\
$\log _{10}$ & $(13.20)^{*}$ & $(13.02)^{* *}$ & 1.509 \\
Cultured CFU $\left(\times 10^{11}\right)$ & $143.67+19.25$ & $104.72+17.19$ & $(13.02)^{* *}$ \\
$\log _{10}$ & $(13.16)^{*}$ & & \\
\hline
\end{tabular}

\footnotetext{
${ }^{* * *}$ Significantly different at $(p<0.001)$, each value is a mean of duplicate readings of 12 fish samples.
} 
Table 2. Enterobacteria load on skin and in stomach of Nile tilapia (Oreochromis niloticus) (n $=12$ fishes $\times$ duplicates readings) count $\left(\times 10^{11}\right)$.

\begin{tabular}{cccc}
\hline & \multicolumn{2}{c}{ Sample Body Parts } & t-Value \\
\hline Sources & Skin & Stomach & $3.629^{* * *}$ \\
\hline Wild CFU $\left(\times 10^{11}\right)$ & $49.00+4.13$ & $74.08+5.55$ & -0.256 \\
$\log _{10}$ & $(12.69)^{*}$ & $(12.86)$ & \\
Cultured CFU $\left(\times 10^{11}\right)$ & $63.83+7.33$ & $67.17+10.74$ & $(12.82)^{* *}$ \\
$\log _{10}$ & $(12.80)^{*}$ &
\end{tabular}

${ }^{*} \log _{10} \mathrm{cfu} / \mathrm{cm}^{2}$ skin; ${ }^{* *} \log _{10} \mathrm{cfu} / \mathrm{g}$ stomach; ${ }^{* * *}$ Significant difference at $(p<0.001)$ each value is a mean of duplicate readings of 12 fish samples.

This could be due to rapid die-off of enteric organisms introduced into water bodies by animal (including bird) manure and human waste [15] [16] and ability to survive more in the stomach than in the water environment. Generally, the bacteria load of all the skin and fish sampled from different aquatic environments were high with indices ranging from $10^{12}$ to $10^{13}$ as compared to the recommended level of $10^{2}-10^{7} / \mathrm{cm}^{2}$ for skin [15] and $10^{3}$ $10 \%$ g of stomach [17].

Therefore the bacterial load found in this study ranging from $1.43 \times 10^{13}-1.59 \times 10^{13} \mathrm{cfu} / \mathrm{cm}^{2}$ for skin samples and $1.04 \times 10^{13}-1.05 \times 10^{13}$ for stomach was beyond the standard value which indicates their unacceptability as food from public health point of view.

High microbial load encountered in this study could be due to mass pollution of water environment which produce dense population of micro-organisms [18]. Animal and human manure, pets especially dogs can contribute to faecal contamination of surface waters. Birds can be a significant source of faecal contamination of water bodies. Swans, geese and other water fowl can elevate bacterial counts in rivers and ponds [19].

The higher density of bacteria in fish body may also be due to secondary contamination during handling and storage. Predominant bacteria isolated from skin and stomach of fish samples are strains of Staphylococcus aureus, Escherichia coli, Proteus species, Bacillus species, Klebsiella species, Micrococcus species, Serratia species, Pseudomonas species, Salmonella species, and Streptococcus species.

All these organisms are potential pathogens of man capable of causing a variety of diseases. Bacillus species, Escherichia coli, Salmonella species, Streptococcus species and Staphylococcus aureus were implicated in fishborne [20] shrimp-borne [21] diseases of humans. Perhaps the best known and most easily recognized of the Gramnegative, facultative anaerobic bacilli are those that currently make up the family Enterobacteriaceae or enteric, as they are commonly called, includes a group of bacteria that inhabit the intestinal tract of humans and other animals. Some species are permanent residents, others are found in only a fraction of the population, and others are present only as disease conditions agents.

It was reported that there is evidence of rapid die-off of enteric organisms and viruses in well managed fish ponds [16], a significant number of organisms can be found in products harvested from waste fed systems and polluted river, and such products therefore pose a potential health risk [22]. There exists great concern over the wide spread use of antibiotics in aquaculture which may result in residue of antibiotics in water and mud and subsequently the development of antibiotics resistance in bacteria in the environment. Different antibiotic resistance patterns in environmental, food and clinical sources have been reported [23]-[26].

Information on antibiotics susceptibility of microbes isolated from fish in Nigeria is scarce hence three strains each of Escherichia coli, Salmonella species, Streptococcus species, and Staphylococcus aureus isolated from wild and cultured Nile tilapia Oreochromis niloticus, were examined for resistance to commonly used antibiotics.

The results of the antibiotics sensitivity test were interpreted and are presented as the resistance of bacterial isolates to the antibiotic resistance pattern among the bacterial isolates (Table 4). Recent studies have shown that many antibiotics persist in the sediment and in the aquatic environments for several months following administration [27] [28]. The residues of antibacterial agents may affects the sedimentary microbial community and introduce antibiotic resistance in the bacteria [29].

In a recent work conducted by a researcher [24] on microbiology of a pharmaceutical effluent discharged into natural water, multi-resistant environmental strains were found. Similar and more multi-resistant strains were found in this study from Nile tilapia, Oreochronus niloticus, sampled from natural water (Eleyele River which 
has evidence of being polluted by industrial and domestic waste. Fish are caught in large quantity for local and regional consumption from this river, representing a potential threat to human health. Over the last decades, a high number of food borne disease outbreaks has occurred, some with high mortality rates. Antibiotic resistance which could lead to ineffective treatment of infections could be responsible for this increased mortality. [30].

High level of resistance was obtained among the bacterial isolates $(33.33 \%-100 \%)$ as shown in Table 3 . None of the antibiotics tested had $100 \%$ activity against all strains of Salmonella isolated form wild tilapia, Gentamicin had 100\% activity against all strains of Escherichia coli, Salmonella and Staphylococcus aureus isolated from wild tilapia while similar effect was on Salmonella strains and Staphylococcus aureus isolated from cultured tilapia. Ofloxacin had 100\% activity against the strains of Streptococcus species isolated from wild tilapia. All strains of E. coli and Streptococcus isolated from cultured tilapia showed various forms of resistance to all the antibiotics.

The cumulative effectiveness of the antibiotics as obtained in this study is Gentamicin $>$ Ofloxacin $>$ Nitrofurantoin $>$ Amoxicillin $>$ Tetracycline $>$ Cotrimoxazole $=$ Nalidixic acid $>$ Augmentin. Our result provides further evidence of multi resistant strains in nature, representing a potential threat to human health. Antibiotic resistance is increasing rapidly and developing countries are the worse affected; since they provide conditions and practices that support the development and spread of resistant microbes. Antibiotics prescriptions in hospitals are given without clear evidence of infection or adequate medical indication [31]. Due to unaffordable laboratory tests and consultation fees, it is becoming popular to prescribe broad spectrum antibiotics that are active against a wide range of different microbes; such antibiotics exposes much more bacteria than is needed, resulting in the consequent risk of dangerous side effects, super infections and the selection of drug resistant mutants. Too much antibiotic in animal feed to prevent intestinal infections could rapidly cause resistance to develop and passed on to human as in Escherichia coli [32].

The rapid development of antibiotic resistant by Salmonella, Staphylococcus, and Streptococcus may have developed in this way.

Six patterns of multiple drug resistant with the number of antibiotics ranging from 3 to 8 among the bacterial isolates were obtained (Table 4) and fall within the range obtained by earlier workers [24] [31] [33] [34]. Our result provides further evidence of the emergence of multi resistant strains in nature representing a potential threat to human health. Previous studies [31] reported that multiple drug resistant is an extremely serious public health problem and it has been associated with outbreaks of major epidemics throughout the world. Thus, the multiple drug resistance showed by these bacteria is worrisome because of the public health implications.

In conclusion, it is recommended that the hygienic handling of fish from the moment of capture to the point of consumption is crucial to ensure good quality and long shelf life. Bacterial contamination of fish is a main cause of spoilage and is of particular importance if the fish is contaminated with pathogenic bacteria, which causes food poisoning or even death amongst consumers. Therefore fish should be kept clean and at chill temperature

Table 3. Resistance of bacterial isolates against individual antibiotics.

\begin{tabular}{|c|c|c|c|c|c|c|c|c|c|}
\hline \multicolumn{10}{|c|}{ Bacterial Isolates } \\
\hline Antibiotics & \#Ec & \#\#Ес & $\# \mathrm{~S}_{\mathrm{A}}$ & $\# \# \mathrm{~S}_{\mathrm{A}}$ & $\#$ Sp & \#\#Sp & $\# \mathrm{~S}_{\mathrm{T}}$ & $\# \# \mathrm{~S}_{\mathrm{T}}$ & Cumulative Resistance \\
\hline Aug & $3(100)$ & $3(100)$ & $3(100)$ & $3(100)$ & $3(100)$ & $3(100)$ & $2(66.67)$ & $1(33.33)$ & $21(87.50)$ \\
\hline Amx & $2(66.67)$ & $3(100)$ & $0(0.0)$ & $1(33.33)$ & $3(100)$ & $3(100)$ & $3(100)$ & $3(100)$ & $18(75.00)$ \\
\hline Cot & $2(66.67)$ & $3(100)$ & $1(33.33)$ & $2(66.67)$ & $3(100)$ & $3(100)$ & $3(100)$ & $3(100)$ & 20(83.33) \\
\hline Gen & $0(0.0)$ & 1(33.33) & $0(0.0)$ & $0(0.0)$ & $3(100)$ & $3(100)$ & $0(0.0)$ & $0(0.0)$ & $7(29.17)$ \\
\hline $\mathrm{Nal}$ & $2(66.67)$ & $2(66.67)$ & $2(66.67)$ & $3(100)$ & $2(66.67)$ & $3(100)$ & $3(100)$ & $3(100)$ & 20(83.33) \\
\hline Nil & $1(33.33)$ & $1(33.33)$ & $3(100)$ & $3(100)$ & $1(33.33)$ & $1(33.33)$ & $2(66.67)$ & 1(33.33) & 13(54.17) \\
\hline Ofx & $2(66.67)$ & $1(33.33)$ & $3(100)$ & $2(66.67)$ & $0(0.0)$ & 1(33.33) & $1(33.33)$ & $2(66.67)$ & $12(50.00)$ \\
\hline Tet & $2(66.67)$ & $3(100)$ & $3(100)$ & $3(100)$ & $3(100)$ & $3(100)$ & $3(100)$ & 1(33.33) & 19(79.17) \\
\hline
\end{tabular}

No of resistant isolates, (\%) in parenthesis, a total of 24 isolates used, three for each bacterium; Ec (E. coli), $\mathrm{S}_{\mathrm{A}}$ (Salmonella). Sp (Streptococcus), St (Staphylococcus aureus). \#, wild tilapia isolates, \#\#, cultured tilapia isolates. 
Table 4. Antibiotic resistance pattern among the bacteria isolates.

\begin{tabular}{|c|c|c|c|c|}
\hline No of Antibiotics & Resistance & Number of Isolate & Bacteria & $\%$ \\
\hline 3 & Amx, Cot, Nal & 1 & \#\#ST & 4.17 \\
\hline \multirow[t]{7}{*}{4} & Aug, Nal, Ofx, Tet & 1 & \#Еc & 4.17 \\
\hline & Aug, Amx, Cot, Nit & 1 & \#Еc & 4.17 \\
\hline & Aug, Nit, Ofx, Tet & 1 & \#SA & 4.17 \\
\hline & Aug, Nal, Nit, Tet & 1 & \#SA & 4.17 \\
\hline & Aug, Amx, Cot, Nal & 1 & \#ST & 4.17 \\
\hline & Amx, Cot, Nal, Nit & 1 & \#ST & 4.17 \\
\hline & Amx, Cot, Nal, Ofx & 1 & \#ST & 4.17 \\
\hline \multirow[t]{3}{*}{5} & Aug, Amx, Cot, Nal, Tet & 1 & \#Еc & 4.17 \\
\hline & Aug, Nal, Nit, Ofx, Tet & 1 & \#SA & 4.17 \\
\hline & Aug, Amx, Cot, Gen, Tet & 1 & $\#$ Sp & 4.17 \\
\hline \multirow[t]{4}{*}{6} & Aug, Amx, Cot, Nal, Ofx, Tet & 2 & \#Ес, \#\#Ес & 8.33 \\
\hline & Aug, Amx, Cot, Gen, Nit, Tet & 1 & \#\#Ес & 4.17 \\
\hline & Aug, Cot, Nal, Nit, Ofx, Tet & 2 & \#SA, \#SA & 8.33 \\
\hline & Aug, Amx, Cot, Gen, Nal, Tet & 3 & $\#$ \#p, \#\#Sp, \#\#Sp & 12.50 \\
\hline \multirow[t]{2}{*}{7} & Aug, Amx, Cot, Nal, Nit, Ofx, Tet & 3 & \#\#SA, \#ST, \#\#ST & 12.50 \\
\hline & Aug, Amx, Cot, Gen, Nal, Nit, Tet & 1 & $\#$ Sp & 4.17 \\
\hline 8 & Aug, Amx, Cot, Gen, Nal, Nit, Ofx, Tet & 1 & \#\#Sp & 4.17 \\
\hline
\end{tabular}

See methods for antibiotics abbreviations.

which can help to minimize or delay the growth of bacteria. Good hygiene practice and proper handlings are necessary to prevent food poisoning associated with consumption of fish.

It is also recommended that more studies are necessary to confirm the incidence and resistant pattern of antibiotics strains in order to provide baseline information for policy maker. There is urgent need for a monitoring system of antibacterial drugs that are being used in aquaculture practices.

\section{References}

[1] FAO (2000) FAO Yearbook. Fisheries Statistics; Aquaculture Production 1998, Vol. 86/2, FAO Fish Ser. No. 56, FAO State. Ser. No. 154, Rome, 169 p.

[2] Steel, R.G.D. and Torrie, J.H. (1980) Principles and Procedures of Statistics. A Biometrical Approach. 2nd Edition, McGraw-Hill Book Co., New York, 688.

[3] Lateef, A. (2004) The Microbiology of a Pharmaceutical Effluents and Its Public Health Implications. World Journal of Microbiology and Biotechnology, 22, 167-171. http://dx.doi.org/10.1023/B:WIBI.0000021752.29468.4e

[4] Hirsch, R., Ternes, T., Haberer, K. and Kratz, K.-L. (1999) Occurrence of Antibiotics in the Aquatic Environment. Science of the Total Environment, 225, 109-118. http://dx.doi.org/10.1016/S0048-9697(98)00337-4

[5] Thomas, P. and Micheal, M. (1999) Tilapia-Life History and Biology: Southern Regional Aquaculture Center Publication. No. 283, March 1999.

[6] Colby, J.W., Enriquez-Ibarr, L. and Flick, G.J.J. (1993) Shelf Life of Fish and Shellfish. In: Charalambous, G., Ed., Shelf Life Studies of Foods and Bererases: Chemeal, Biological, Physical and Nutritional Aspects, Elsevier, Amsterdam, 85-143.

[7] Sivertsvik, M., Jeksrud, W.K. and Rosnes, J.T. (2002) A Review of Modified Atmosphere Packaging of Fish and Fishery Products-Significance of Microbial Growth Activities and Safety. International Journal of Food Science and 
Technology, 37, 107-127.

[8] Raghavan, R.P. (2003) Incidence of Human Pathogenic Bacteria in Shrimps Feeds: A Study from India. WorldFish Centre Quarterly, 26, 22-24.

[9] Buchanan, R.M. and Gibbons, N.E. (1974) Bergey’s Manual of Determinative Bacteriology. 8th Edition, The Williams and Wilkins Company, Baltimore.

[10] Ojo, O.O. (2008) Consumption Pattern of Fish among Households in Ibadan North Local Government Area of Oyo State (An Unpublished B.Sc. Project). Department of Agricultural Economics, Bowen University Iwo, Nigeria.

[11] Babu, P.S. (2000) Ichyozoonoses. Fish Farmer International, 14, 14-17.

[12] Huss, H.H., Ababoulogy, L. and Gram, L. (2003) Assessment and Management of Seafood Safety and Quality. FAO, Rome.

[13] Steel, R.G.D. and Torrie J.H. (1980) Principles and Procedures of Statistics. A Biometrical Approach. 2nd Edition, M.C. Graw-Hill Book Co., New York, 688.

[14] Horsley, R.W. (1977) A Review of Bacterial Foora of Teleosts and Elasmobranches, Including Methods for Its Analysis. Journal of Fish Biology, 10, 529-533. http://dx.doi.org/10.1111/j.1095-8649.1977.tb04086.x

[15] Edward, P. and Pullin, R.S.V. (1990) Wastewater Fed Aquaculture. Proceedings of the International Seminar on Wastewater Reclamation and Reuse for Aquaculture, Calcutta, 6 December 1988; Bangkok, Asian Institute of Technology, Environmental Sanitation Information Center.

[16] Chortyk, T.O., Severson, R.F., Cutler, H.C. and Siesson, V.A. (1993) Antibiotic Activities of Sugar Esters Isolated from Selected Nicotiana Species. Bioscience, Biotechnology, and Biochemistry, 57, 1355-1356. http://dx.doi.org/10.1271/bbb.57.1355

[17] Okafor, N. (1985) Aquatic and Waste Microbiology. Fourth Dimension Publishing Company Ltd., Enugu, $187-219$.

[18] Hansen, J.M., Gerner-Sinidt, P. and Bruun, B. (2005) Antibiotics Susceptibility of Listeria monocytogenes in Denmark 1958-2001. APMIS, 113, 31-36. http://dx.doi.org/10.1111/j.1600-0463.2005.apm1130105.x

[19] Bauer, A.W., Kirby, W.M.M., Sherris, J.C. and Turck, M. (1966) Antibiotic Susceptibility Testing by a Standard Single Disc Diffusion Method. American Journal of Clinical Pathology, 45, 493-496.

[20] Olagunju, F.I., Adesiyan, I.O. and Ezekie, A.A. (2007) Economic Viability of Catfish Production on Oyo State, Aligeria. Journal of Human Ecology, 21, 121-124.

[21] Hektoen, H., Berge, J.A., Hormazabal, V. and Yndeslad, M. (1995) Persistence of Antibacterial Agents in Marine Sediments. Aquaculture, 133, 175-184. http://dx.doi.org/10.1016/0044-8486(94)00310-K

[22] Raghavan, R.P. (2003) Incidence of Human Pathogenic Bacteria in Shrimps Feeds. A Study From India. NAGA. Worldfish Centre Quarterly, 26, 22-24.

[23] Sugita, H., Miyajima, C. and Deguchi, Y. (1991) The Vitamin B 12 -Producing Ability of the Intestinal Microflora of Freshwater Fish. Aquaculture, 92, 267-276.

[24] Edward, P. and Pullin, R.S.V. (1990) Wastewater Fed Aquaculture. Proceedings of the International Seminar on Wastewater Reclamation and Reuse for Aquaculture, Calcutta, 6 December 1988; Bangkok, Asian Institute of Technology, Environmental Sanitation Information Center.

[25] Walsh, D., Duffy, G., Sheridan, J.J., Blair, I.S. and McDowell, D.A. (2001) Antibiotics Resistance among Listeria, Including Listeria monocytogenes, in Retail Foods. Journal of Applied Microbiology, 90, 517-522. http://dx.doi.org/10.1046/j.1365-2672.2001.01273.x

[26] Miranda, C.D. and Zemelmar, R. (2002) Bacteria Resistance to Oxytetracycline in Chilean Salmon Farming. Aquaculture, 212, 31-47. http://dx.doi.org/10.1016/S0044-8486(02)00124-2

[27] Doyle, M.P. and Ericson, M.C. (2006) Closing the Door on the Fecal Coliform Assay. Microbe, 1, 162-163.

[28] Paclorek, J. (2004) Antimicrobial Susceptibilities of Listeria monocytogenes Strains Isolated from 2000 to 2002 in Poland. Polish Journal of Microbiology, 53, 279-281.

[29] Hirsch, R., Ternes, T., Haberer, K. and Kratz, K.-L. (1999) Occurrence of Antibiotics in the Aquatic Environment. Science of the Total Environment, 225, 109-118. http://dx.doi.org/10.1016/S0048-9697(98)00337-4

[30] Levy, S.B. (1997) Antibiotic Resistance an Ecological Imbalance. In: Chandwick, D.J. and Goode, J., Eds., Antibiotic Resistance: Origins, Evolution Selection and Spread, Wiley, London, (Ciba Foundation Symposium 207), 1-14.

[31] Prescott, M.L., Harley, J., Donald, P. and Klein, A. (1999) Antimicrobial Chemotherapy. In: Microbiology, 2nd Edition, C. Brown Publishers, USA, 325.

[32] Buras, N. (1993) Microbial Safety of Produce from Wastewater-Fed Aquaculture. In: Pullin, R.V.C., Rosenthal, H. and Maclean, J.L., Eds., Environment and Aquaculture in Developing Countries, Proceeding of the 31st ICCLARM Conference Manila, International Center for Living and Aquatic Resources, 285-295. 
[33] Prescott, M.L., Harley, J., Donald, P. and Klein A. (1999) Antimicrobial Chemotherapy. Microbiology. 2nd Edition, C. Brown Publishers, Dubuque, 325.

[34] Lateef, A. (2004) The Microbiology of a Pharmaceutical Effluents and Its Public Health Implications. World Journal of Microbiology and Biotechnology, 22, 167-171. http://dx.doi.org/10.1023/B:WIBI.0000021752.29468.4e 